TOMASZ NOWICKI* - LUBLIN

\title{
DOS ECCLESIAE AND DOS PAROCHII ILLUSTRATED WITH AN EXAMPLE OF THE CANONICAL VISITATION OF THE PARISHES IN THE DIOCESE OF WLOCŁAWEK IN THE YEARS 1710-1711
}

In the modern period, the same as in the Middle Ages, the proper functioning of the parish was dependent on the appropriate endowment, which provided it with sufficient material support. Without this, it was not possible to erect a new parish. At that time the endowment included:

1. Land properties (arable fields, meadows, orchards and gardens, woods, ponds or lakes);

2. Building properties (buildings, outbuildings, livestock, mills, taverns and presbyteries);

3. Payments made by people (tithe, missalia- a payment for celebrating a mass, mensalia-a payment made mainly by landless people and smallholders during Easter time, a payment for priest's visit during Christmas time, occasional payments);

4. Foundational bequests (pious and testamentary bequests)

5. Property rights (e.g. free propination, free fishing, free use of king's or landowner's forests)

Endowment was supposed to serve two purposes. On the one hand its aim was to meet the needs of the priest - an administrator of that benefice. This part of the endowment, i.e. dos parochii (in other words proventus parochi, bona beneficialia or peculim clericale), was only available to that priest, because it was the pay for his pastoral work according to the principle expressed at the Synod organized by Archbishop Jakub Świnka in 1309, which said propter officium debetur benefici$u m^{1}$. On the other hand, expenses associated with creating and then maintaining the parish did not refer only to providing a priest with board and lodging. It was

* Tomasz Nowicki - dr hab. historii, adiunkt w Katedrze Ustroju i Administracji Polski, dyrektor Instytutu Historii KUL, e-mail: tonowi@kul.pl

${ }^{1}$ Vide W. Wójcik, „Prawa parafialne” wedtug polskiego ustawodawstwa partykularnego do 1564 r., „Roczniku Teologiczno-Kanoniczne”, 3 (1957), issue 2, pp. 174-175. 
also necessary to maintain the church and its surroundings, that is so called "the factory of the church". Therefore, the synodal statutes determined what part and what types of benefice income should be used for maintaining the $\mathrm{church}^{2}$. Also, some canonical visitations included, in addition to the above-mentioned endowment for the priest, a different kind of endowment called dos ecclesiae, proventus ecclesiae, reditus ecclesiae, bona fabricae or peculium ecclesiasticum.

There is one question worth asking: who managed these two components of the parish property? In the case of the priest's endowment the answer is clear. It was the parish manager who had that income at his disposal for his pastoral efforts. More complicated issue is the question of managing the assets allocated for maintaining the church. Originally, the church law entrusted the managing of this income to the clergy. It was even forbidden to involve laypeople to do this task. Such records can be found in the aforesaid Decretum Gratiani or in the canons of the Lateran Council of $1123^{3}$. The practice, however, went in the other direction. It concerned especially the parish benefice, where lay founders and their heirs played a significant role. Also, other laypeople, connected with their parish church, and at the same time becoming more and more aware and concerned for its material condition, tried to gain influence over the management of the assets allocated for the church. The situation in which the church revenues were managed both by lay parishioners and priests was already known in the mid- $12^{\text {th }}$ century in Italy and England. In the $13^{\text {th }}$ century, it became widespread in France and Germany, and by the end of the $14^{\text {th }}$ century, it spread to the entire Latin Europe. Finally, the custom was sanctioned by the Church at the Council of Trent ${ }^{4}$. It is worth noting that in Poland, the traces of cooperation between the clergy and laity in managing part of the church property can be observed at least at the beginning of the $14^{\text {th }}$ century, but most particularly these issues were regulated at the provincial synod of Kalisz of 1420 called by Archbishop Mikołaj Trąba ${ }^{5}$.

${ }^{2}$ Vide K. Karłowski, Z dziejów zarządu majątku kościelnego, „Miesięcznik Kościelny. Organ Archidiecezji Gnieźnieńskiej i Poznańskiej”, 51(1936), pp. 209-210; S. Sołtyszewski, Dochody kościelne pod zarządem witrykusów w polskim ustawodawstwie synodalnym, „Prawo Kanoniczne” ,3 (1960), no 3-4, p. 312; idem, Zarzą majątkiem kościelnym w kanonicznym ustawodawstwie powszechnym, „Prawo Kanoniczne” 3 (1960), no 3-4, pp. 335-336; J. Wiśniewski, Fabrica ecclesiae na terenie oficjalatu pomezańskiego w świetle wizytacji biskupów XVII-XVIII w., part 1: „Archiwista Polski”, 12 (2007), no 2, p. 50; cf. T. Nowicki, Uposażenie kleru parafialnego $w$ archidiakonacie pomorskim w XVIII wieku, „Roczniki Humanistyczne”, 51 (2003), issue 2, p. 48; idem, Carbona ecclesiae - przyczynek do badań nad dochodowościa kościołów parafialnych $w$ archidiakonacie pomorskim na przykładzie wizytacji biskupa Rybińskiego z 1780-1781 roku, „Studia Pelplińskie” 42 (2010), special edition, p. 249.

${ }^{3}$ Vide K. Karłowski, op. cit., p. 210; S. Sołtyszewski, Zarzad..., pp. 336-340, B. Kumor, Kościelne stowarzyszenia świeckich na ziemiach polskich $w$ okresie przedrozbiorowym, „Prawo Kanoniczne", 10 (1967), no 1-2, p. 314.

${ }^{4}$ K. Karłowski, op. cit., p. 211; S. Sołtyszewski, Zarząd.., p. 343; B. Kumor, op. cit., pp. 314 315.

${ }^{5}$ The first synodal regulations concerning witrycy were introduced at the Synod of Krakow called by Bishop Nanker in 1320. The provincial synod of 1420 organized by Archbishop Mikołaj Trąba decided that witrycy should be appointed in every parish. A number of reasons were given 
In practice, the cooperation was implemented through elected or appointed laypeople. They had different names. They were most often called witrycy, witrykusi, prowizorzy, sometimes treasurers, guardians, custodians or the ministers of the church ${ }^{6}$. Their primary duty was the management and supervision of the church property intended for the factory of the church. They performed this duty by charging the rent for the leased land, buildings and foundational bequests; they collected offerings on Sundays and other feasts, collected a fee payable to the church for funerals and using bells. The collected money was deposited in the church treasury, access to which was usually protected at least with two locks. The parish priest had one key, witrycy the other one. They were obliged to keep accurate settlement of revenues and expenditures from the treasury and to make accurate reports on the management once a year. They were also obliged to conduct inventories, especially of the ecclesiastical equipment. Their task was to maintain order in the church and its surroundings, protect church property, perform minor repairs to the cemetery fence or church buildings, monitor and control contractors in the case of major repairs?

Discussing the issue of endowment, it is worth noting that there were problems associated with separation of the priest's endowment and the one which was allocated for the church. It is necessary to mark that even in the $18^{\text {th }}$-century church visitations these two types of endowments were not isolated although, as already indicated, such a division was known in the church law in the Middle Ages. They were usually discussed together while describing the endowment of the parish. There were also probably the situations when even if dos parochi and dos ecclesiae were differentiated, they were managed by the parish priest who was the chief administrator of the church property. But then he had to designate the

why it was a necessary decision. It was especially emphasized that giving church property to one man, even a priest, is inadvisable and dangerous. These canons gained approval of the Holy See. Vide K. Karłowski, op. cit., p. 211; S. Sołtyszewski, Geneza instytucji witrykusów w polskim ustawodawstwie synodalnym, „Prawo Kanoniczne”, 2 (1959), no 1-2, pp. 431-434; B. Kumor, op. cit., pp. 315-316; E. Wiśniowski, Udziat świeckich w zarzadzie parafia w średniowiecznej Polsce, „Roczniki Humanistyczne”, 18 (1970), pp. 55-56.

${ }^{6}$ About the names of the church prowizorzy vide K. Karłowski, op. cit., pp. 211; S. Sołtyszewski, Geneza..., pp. 425-427; idem, Powoływanie witrykusów w polskim ustawodawstwie synodalnym, „Prawo Kanoniczne”, 2 (1959), no 3-4, pp. 341-347; W. Wójcik, Instytucja witrykusów w świetle śląskich protokołów wizytacyjnych z XVII wieku, „Prawo Kanoniczne”, 6 (1963), no 1-2, pp. 5152; E. Wiśniowski, ibidem, p. 55; T. Nowicki, Ministri ecclesiae. Stużba kościelna i witrycy w diecezji włocławskiej w XVIII wieku, Lublin 2011, pp. 64-72.

${ }^{7}$ The issues of witrycy's duties and tasks vide K. Karłowski, op. cit., p. 212; S. Sołtyszewski, Prawa i obowiazki witrykusów w polskim ustawodawstwie synodalnym, „Prawo Kanoniczne”, 3 (1960), no 1-2, pp. 263-287; W. Wójcik, op. cit., pp. 59-71; B. Kumor, op. cit., p. 317; E. Wiśniowski, op. cit., pp. 59-64; T. Nowicki, Przysięga witryków z początku XIX wieku-przyczynek do badań nad udziatem świeckich $w$ zarządzie dobrami kościelnymi, in: Narrata de fontibus hausta. Studia nad problematyka kościelna, polityczna i archiwistycznq ofiarowane Janowi Skarbkowi w siedemdziesiąta rocznicę urodzin, ed. A. Barańska, W. Matwiejczyk, Lublin 2010, pp.235-238; idem, Ministri ecclesiae..., pp. 216-227. 
necessary resources from the total income coming from the benefice - so from his own one as well as that intended for the church ${ }^{8}$.

This lack of uniformity, mentioned a moment ago, in determining and distinguishing the priest's and church's income is also visible in visitations of the Diocese of Włocławek. The following article presents the issue of endowment for maintaining the church based on the visitation of Bishop Konstanty Felicjan Szaniawski conducted in the whole diocese in the years 1710-1712 .

As is known, the pre-partition Diocese of Włocławek consisted of three archdeaconries, i.e. Włocławek covering eastern Kujawy similar to the territory of the province of Brześć and Kujawy with Włocławek, Brześć Kujawski and Radziejów. Then the Archdeaconry of Kruszwica including Kruszwica, Bydgoszcz and Inowrocław. This area was basically the same as the province of Inowrocław. In the northern part of the diocese there was the Archdeaconry of Pomorze covering $2 / 3$ of the former province of Pomorze without the south-western part forming the Archdeaconry of Kamień, which was the part of the Archdiocese of Gniezno. The largest city in this archdeaconry was obviously Gdańsk, and a smaller one Świecie in the south, Starogard and Tczew in the middle part and Puck in the north.

Clearly meridional shape of the territory, and also different political fate of these lands allow us to divide the Diocese of Włocławek into two different areas. Firstly, the mere glance at the map shows that the Archdeaconry of Pomorze is a geographically separate part ${ }^{10}$. What is more, its area covering 11.656 square kilometres is more than $63 \%$ of the total area of the diocese. All archdeaconries of Kujawy were not bigger than that one archdeaconry ${ }^{11}$. Secondly, the political history of the lands included in the Archdeaconry of Pomorze was different. Its difference reached the beginning of the Middle Ages. They were undoubtedly associated with separate and independent Eastern Pomorze in the period of regionalization of Poland, then the fact that this area was part of the State of the Teutonic

${ }^{8}$ Some diocesan statutes required that. Cf. S. Sołtyszewski, Dochody kościelne..., p. 312.

${ }^{9}$ The documentation of this visitation is available in three different diocesan archives. The visitation book for the Archdeaconry of Pomorze is stored in the Diocesan Archive in Pelplin: Archidiaconatus Pomeraniae sub auspiciis (...) Constantini Feliciani de Szaniawy Szaniawski Episcopi Vladislaviensis et Pomeraniae per Joannem Casimirum Jugowski, Archidiaconum Pomeraniae visitatus A.D. 1710 et A.D. 1711, reference number G26 [ADPel., G26]. In the Archdiocesan Archive in Gniezno there is one copy of this visitation including the Archdeaconry of Kruszwica: Visitatio archidaconatus Crusvicensis ex mandato (...) Constantini Szaniawski Dei et Apostolicae Sedis gratia episcopi Cuiaviensis et Pomeraniae per (...) Paulum Wolski, cancelarium Vladislaviensem archidiaconum Crusvicensem expedita Anno Dni 1712, reference number E8 [AAGn., E8]. In the Diocesan Archive in Włocławek there is part including parishes in the Archdeaconry of Włocławek: Visitatio ecclesiarum parochialium in archidaconatu Vladislaviensi, sub felici regimine (...) Constantini Feliciani Szaniawski, Dei et Apostolicae Sedis gratia episcopi Vladislaviens[si] et Pomeraniae, per (...) Joannem Stanislaum Borzysławski, archidaconum Vladislaviensem in anno Dni millesimo sepingentesimo undecimo expedita, reference number W14(75) [ADWł., G26].

${ }^{10}$ Vide S. Litak, Atlas Kościoła łacińskiego w Rzeczypospolitej Obojga Narodów w XVIII w., Lublin 2006, pp. 120-121.

${ }^{11}$ Vide S. Litak, Kościół taciński w Rzeczypospolitej około 1772 r., Lublin 1996, p. 124; idem, Atlas..., p. 91. 
Knights. These differences, sealed in the second Peace of Torun, in which Royal Prussia gained autonomy, were approved in 1569 by the Union of Lublin. They were also reflected in the ecclesial life of the diocese. It is worth mentioning that in the $16^{\text {th }}$ century, Bishop Stanisław Karnowski had a title episcopus Wladislaviensis et Pomeraniae, which was also used by his successors. ${ }^{12}$ The studied sources often included the name of the Diocese of Pomorze instead of Archdeaconry. ${ }^{13}$

Additionally, in 1765, Bishop Ostrowski, together with the Chapter asked the Holy See to appoint a separate Suffragan Bishop of Pomorze, giving a variety of reasons ${ }^{14}$. The king supported the request, which helped to accelerate the case in Rome. Pope Clement XIII, in February 1766, nominated the first Suffragan Bishop of Pomorze Cyprian Wolicki ${ }^{15}$. The appointment of a bishop resident in Gdańsk, although it occurred relatively late, confirmed the considerable differences between Kujawy and Pomorze.

The differences between archdeaconries in the Diocese of Włocławek had also an impact on the presence of laypeople such as prowizorzy in the parishes of the diocese in the $18^{\text {th }}$ century. When we compare the size of this group in the parishes located in each archdeaconry of the diocese in the $18^{\text {th }}$ century, it turns out that at the beginning of the century they were recorded in almost $56 \%$ of the parishes in Pomorze, just over 30\% of the parishes in Włocławek and only $2 \%$ of the parishes in Kujawy. Half a century later, the disproportion was even more visible: witrycy were in $76 \%$ of the parishes in Pomorze, $27 \%$ in Włocławek and only $9 \%$ in Kruszwica. Significant improvement in the Archdeaconries of $\mathrm{Ku}-$ jawy was recorded in the visitation of Bishop Józef Rybiński in the early 1780s, but the highest percentage of parishes with witrycy was in the Archdeaconry of Pomorze. In Pomorze there were more than $94 \%$ of parishes, in the Archdeaconry of Kruszwica almost $71 \%$, while in Włocławek $57 \%$. It is worth noting that in the Archdeaconry of Pomorze there were also prowizorzy at auxiliary churches ${ }^{16}$.

${ }^{12}$ Such a title was introduced in the provincial synod in Piotrków in 1551. (Vide J. Gręźlikowski, Recepcja reformy trydenckiej $w$ diecezji włoctawskiej $w$ świetle ustawodawstwa synodalnego, Włocławek 2000, p. 109). For example, in the heading of the synodal statutes of the Diocese of Włocławek of 1568 we can read: Stanislaus Carncovius, Dei gratia, Wladislaviensis et Pomeraniae Episcopus (vide Statuta synodalia Dioecesis Wladislaviensis et Pomeraniae, collegit et edidit Zeno Chodyński, Varsaviae 1890, p. 38). In the earlier synod of 1539 Bishop Lukasz Górka, the same as his predecessors, used only Episcopus Wladislaviesis (vide ibidem, p. 36).

${ }^{13}$ For example, the priests coming from the Archdeaconry of Pomorze were most often referred to as the ones coming from the Diocese of Pomorze. Vide T. Nowicki, Territoriale Herkunft der katholischen Geistlichkeit im Archidiakonat Pommerellen im 18. Jahrhundert, "Zeitschrift für Ostmitteleuropa-Forschung" 49 (2000), Hf. 1, p. 24.

${ }^{14}$ Attention was especially paid to the senatorial rank of the Ordinary, forcing him to stay with the king in Warsaw, which in turn forced the Auxiliary Bishop of Włocławek to reside in the capital of the diocese and the cathedral. And therefore it was difficult for this bishop to fulfil his duties in Pomorze because of considerable distance. The Bishop of Pomorze was needed to strengthen the faith and seriousness of the Catholic Church in the area where there was strong Lutheran influence (vide S. Chodyński, Biskupi sufragani włocławscy, Włocławek 1906, pp. 85-86).

${ }^{15}$ Ibidem, pp. 86-87.

${ }^{16}$ Vide T. Nowicki, Ministri ecclesiae..., pp. 93-95. 
The issue of the presence of witrycy in parishes of the Diocese of Włocławek is presented graphically in the graph below.

\section{Graph 1. The percentage of the parishes in the diocese with witrycy according to archdeaconries in the $18^{\text {th }}$ century}

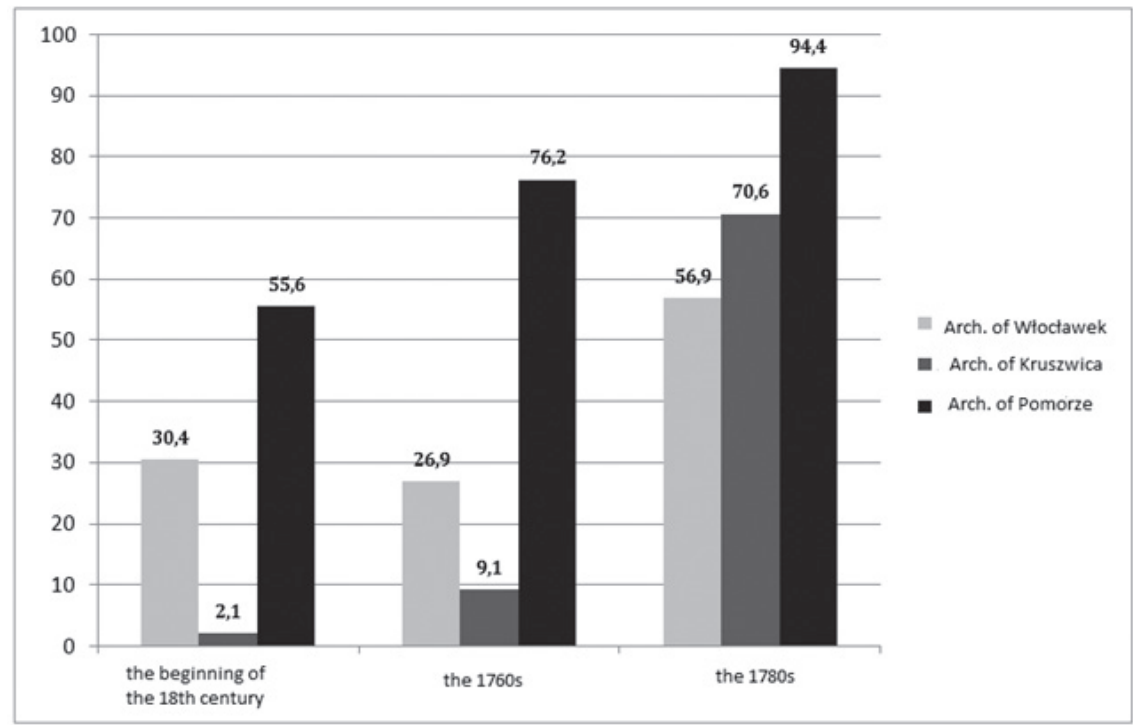

[T. Nowicki, Ministri ecclesiae..., p. 93]

There is also another example of the issue concerning the parish endowment, which refers to the significant differences between the Archdeaconry of Pomorze and two Archdeaconries of Kujawy. Just ask the question, who paid those who worked for the parish in the $18^{\text {th }}$ century? It turns out that in the Archdeaconry of Pomorze, as confirmed by visitation sources, the fixed salary for those people usually came from the endowment allocated to the church. Referring to the visitations which are the basis of these considerations, we can provide numerous records indicating that the certain minister salariatur ab ecclesia, often stating the amount which was paid ${ }^{17}$. Sometimes it was literally stated that a church servant was paid by witrycy, which must mean that the funds were strictly church ones ${ }^{18}$. In the parishes of Kruszwica and Włocławek the most common information is that the parish manager gave the salary to an organist, cantor or teacher ${ }^{19}$. There is no

${ }^{17}$ For example, in the parish of Lipusz the visitor noted down: Organarius qui simul et Baccalaurei Officium habet salariatur a Parochianis percipiendo medium modium siliginis a Singulis a quibus Parochus percipit modium. Ab Ecclesia percipit fl. 2 (vide ADPel., G26, p. 13).

${ }^{18}$ For example, in the visitation of the parish of Kościerzyna in 1710 there appeared a record that a teacher and organist Solariantur ambo partim a Civibus partim a Vitricis ecclesiae partim etiam a Confratribus Sanctissimi Rosarii juxta legationes et fundationes suas (vide ibidem, pp.5-6).

${ }^{19}$ A number of examples can be found in Bishop Szaniawski's visitation. In the parish of Włocławek the visitor noted down that Organarius adpraesens Bartholomeus Gorski Cathedralis sal- 
information in the visitations of the parishes of Kujawy about allotting income from the buildings, land and rents, which was strictly intended for the factory of the church, to the maintenance of the church building and its surroundings. The current needs were most often met by contributions from the faithful and funeral fees. They probably did not generate high revenue so church servants had to be paid from other sources. In the cities, these salaries were sometimes partly paid by the municipal council. Such examples can also be found in the cities of Pomorze.

The following graph shows the sources of the fixed salary paid to the church servants of the Diocese of Włocławek in the18th century.

Graph 2. The sources of the fixed salaries paid to the church servants in the Diocese of Wloclawek in the 18th century with the division into archdeaconries

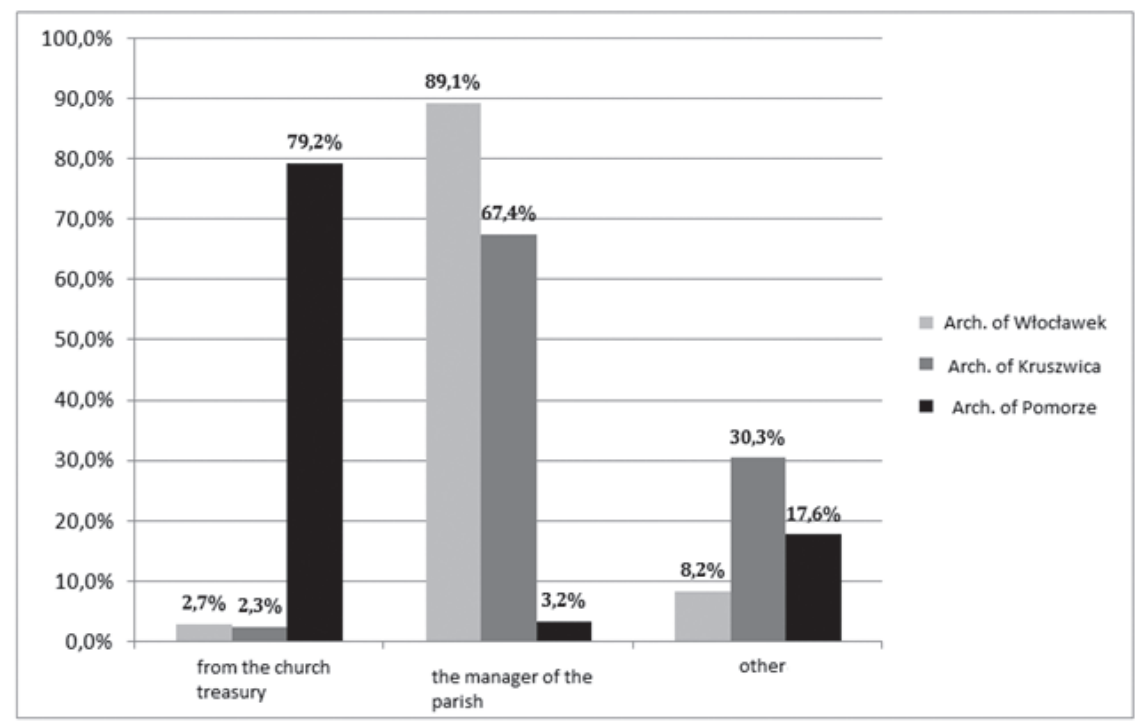

[T. Nowicki, Ministri ecclesiae..., p. 339]

As the graph shows, in the Archdeaconry of Pomorze $79 \%$ of church servants were paid from the church treasury, in the Archdeaconry of Kruszwica more than $67 \%$ of them were paid by the parish manager. This percentage was even higher in the Archdeaconry of Włocławek. More than $89 \%$ of church servants were paid by the parish priest ${ }^{20}$. The above example also shows the uniqueness of the Archdeaconry of Pomorze in the Diocese of Włocławek. It clearly stands out from the two Archdeaconries of Kujawy. The fact that in Kujawy church servants were supported typically by parish managers suggests that local parishes, in contrast to Pomorze, did not have separate endowment for the priest and church.

ariatur secundum posse a Rndo Parocho (vide ADWł., W14(75), column 73). The similar situation was in Kowal, where an organist, apart from other forms of endowment, habet (...) a Dno Praeposito intuitu salarii pro quolibet quartuali florenos decem (vide ibidem, column 88).

${ }^{20}$ Vide T. Nowicki, Ministri ecclesiae..., p. 339. 
The above findings concerning certain separateness of the archdeaconries of the Diocese of Włocławek are also confirmed by the analysis of the source records of the benefice and church endowment recorded in Bishop Szaniawski's visitation. It turns out that in the Archdeaconry of Pomorze at the level of subheadings of the visitation, dos ecclesiae and dos parochii were differentiated. No such division can be found in the visitations in the parishes of Kujawy. While discussing endowment, a visitor described everything in one section entitled frequently dos ecclesiae. The analysis of the records shows that under this name referred to the priest's endowment, which covered his cost of living. These revenues were also allotted to maintaining church buildings. The records sometimes mentioned some intentionally bequeathed income for the church, for example funds for individual altars or interior lighting. Such revenues were excluded from the total endowment, and they were discussed separately ${ }^{21}$.

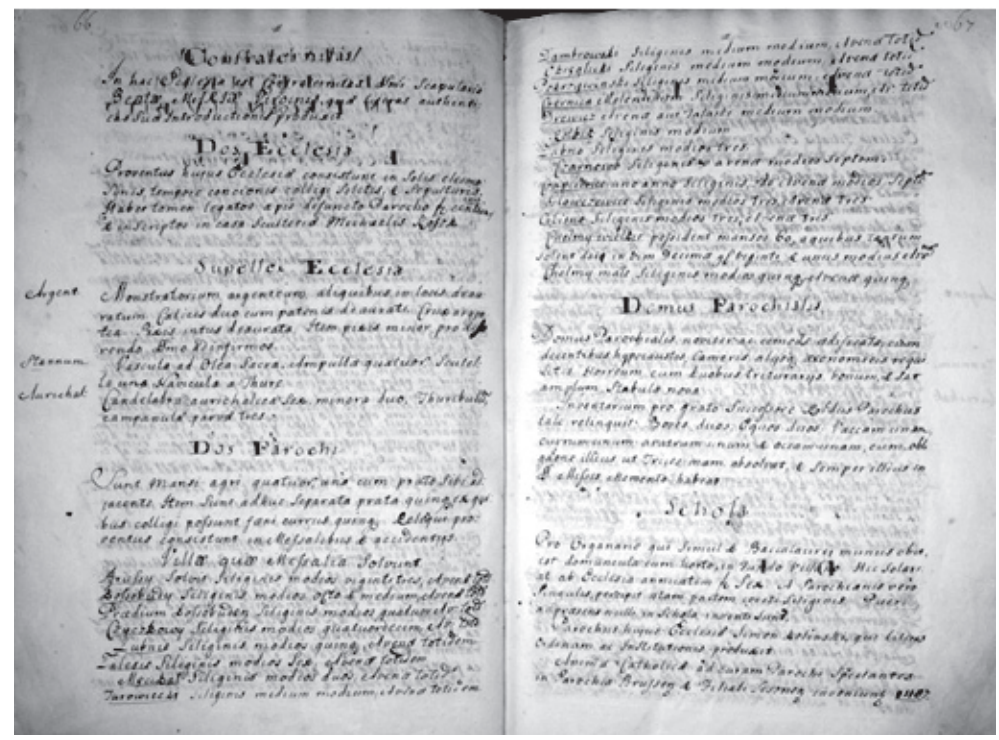

The visitation report of the parish in Brusy (Archdeaconry of Pomorze, Deanery of Bytów) of 1711 with a clear distinction between the endowment allocated to the priest and church (Vide ADPel., G26, pp. 66-67).

${ }^{21}$ For example, in the parish of Kruszyn in the Archdeaconry of Włocławek, in the visitation there is a separate description of endowment called dos ecclesiae, but it was certainly intended for a parish priest, as evidenced by the described elements of the endowment (manor, outbuildings, additional 2 fields sown by the parish priest, meadows) and no separate point mentioning the endowment for the factory of the church. What is more, the record is finished with the words: ... omnium, tam Agrorum quam Pratorum est possessione et usu (...) modernus Parochus (vide ADWł., W14(75), column 54). Only in the part concerning the rent there is information about the testamentary bequest of Podstoli of Podole Stefan Jaranowski, who gave 3 thousand Polish florins to ornament and embellish the high altar (vide ibidem, column 54v). Furthermore, in the parish church dedicated to John the Baptist in Włocławek- apart from a detail description of the land endowment, tithe and income from rent and bequests-there is information about separate funds and endowment allocated to the Chapel dedicated to 5 Wounds of Christ and a few altars which were in the same church (vide ibidem, columns $67 \mathrm{v}-72$ ). 
At this point, it is worth analyzing the records concerning the endowment for the parishes of Pomorze. In 135 protocols describing parish and branch churches or even chapels, in 64 cases dos ecclesiae and dos parochii $(47,4 \%)$ were differentiated $^{22}$. In further 27 protocols $(20.0 \%)$ the funds for the factory of the church were not described separately, but it is known that the church servants (usually at that time teachers and organists) received salaries from this source, and not from the parish priest. This means that even in these parishes there was separate income intended for the church, and different from the priest's income ${ }^{23}$. In conclusion, we can say that in more than $67 \%$ of church centres in Pomorze, recorded in Bishop Szaniawski's visitation, we can find information about the funds intended for the church. There was no such endowment in the case of 6 churches, as evidenced by appropriate source records ${ }^{24}$. On the other hand, there was a fairly large group of the churches about which there is no information if they had a separate fund for the factory of the church. They accounted for over $28 \%$ of the described sacred objects $^{25}$. If parish churches are only taken into consideration, then the percentage of those with separate endowment for the church will rise to almost $73 \%{ }^{26}$. In the case of subsidiaries or affiliated parishes more than $57 \%$ had separate endowment for the factory of the church ${ }^{27}$. The graph below illustrates the discussed issues.

${ }^{22}$ For example, the first visitation record describing the parish in Kościerzyn presents separately proventus ecclesiae and proventus parochii (vide ADPel., G26, pp. 2, 3).

${ }^{23}$ For example, in the parish of Strzepcz there is no separate information about the income strictly allocated to the factory of the church. It is known, however, that an organist and teacher received the endowment in the form of grain from parishioners. They also received, apart from usual occasional payments, 4 florins from the church in Strzepcz and the same amount from the church in Sianów (vide ibidem, p. 28).

${ }^{24}$ All these cases referred to affiliated churches or parishes. In 3 of them there was even no endowment for the parish priest: in the church in Przywidz (Deanery of Gdański, vide ibidem, p. 134), in Sartawice (Deanery of Świecie, vide ibidem, p. 272) and in Studzienice (Deanery of Bytów, vide ibidem, p. 83). In Dalwin (Deanery of Tczew, vide ibidem, p. 162) and in two churches from the Deanery of Starogard, that is in Łęg (vide ibidem, p. 123) and Nowa Wieś (vide ibidem, p. 112) the visitor noted down the separate endowment for the church manager, but he marked that there was no endowment for the church.

${ }^{25}$ In this case it refers to the reports of such churches where there is no information about a separate fund for the church and there are no traces of witrycy paying the church servants.

${ }^{26} 39$ parishes with a clearly separate church fund, 25 with the information about supporting a teacher or organist from the church fund, that is 64 parishes out of 88 .

${ }^{27}$ In 25 dos ecclesiae was distinguished, in other two there was information about supporting a teacher or organist from the church fund, that is 27 churches out of 47 . 


\section{Graph 3. The endowment for the factory of the church in the churches of the Archdeaconry of Pomorze based on Bishop K.F. Szniawski's visitation of the years 1710-1711}

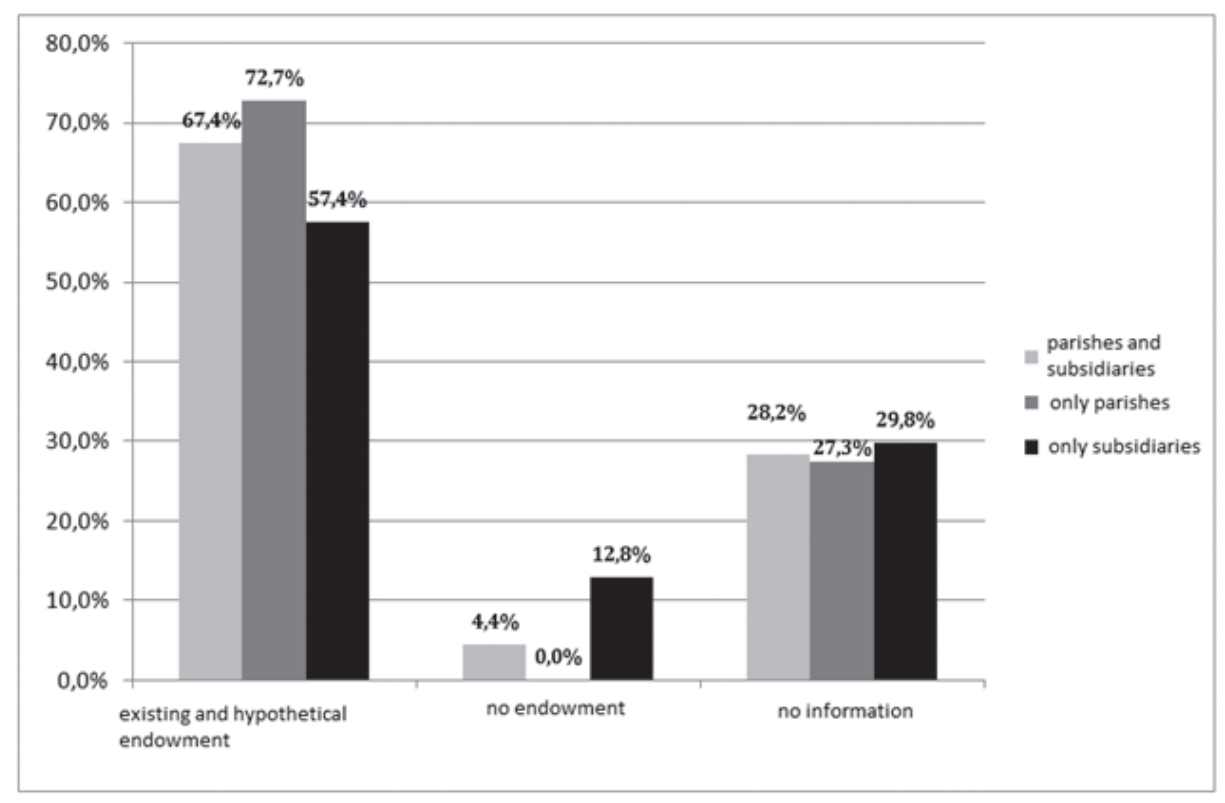

At this point the following question arises, why did Szaniawski's visitors differentiate the church's revenues from the priest's ones in the case of many churches in Pomorze. This may be explained by a detailed analysis of specific source records. It transpires that in the vast majority of such cases the church income did not only come from the typical sources such as offerings collected during religious services or funeral fees. The endowment intended for the church was isolated from the priest's one in the situation when there were other income sources, which included most often real estate such as houses, cottages or apartments. As many as 36 churches out of 135 had such salary (nearly $27 \%)^{28} .29$ churches possessed different types of land $(21.5 \%)^{29}, 14$ received income from a variety of financial bequests and legacies (which accounted for over $10 \%)^{30}$. There were also other sources of revenue for the church, but less frequent, such as wild beehives or cattle received as a legacy. All proceeds from these sources of revenue for the church were placed in the church treasury, and the parish priest together with witrycy decided on what purposed that money had to be spent. These relationships are graphically presented in the following graph.

${ }^{28}$ In the late 1770 s and early 1780 s there were about $23 \%$ of such churches. Vide T. Nowicki, Carbona ecclesiae..., p. 252.

${ }^{29}$ The similar situation was in the years $1780-1781$, when $21,7 \%$ parishes and affiliated parishes had this element of endowment. Vide ibidem.

${ }^{30}$ At the beginning of the $80 \mathrm{~s}, 15.5 \%$ of churches had funds from legacies and financial bequests. Vide ibidem. 
Graph 4. Types of endowment for the church in the Archdeaconry of Pomorze based on Bishop K. F. Szaniawski's visitation of the years 1710-1711

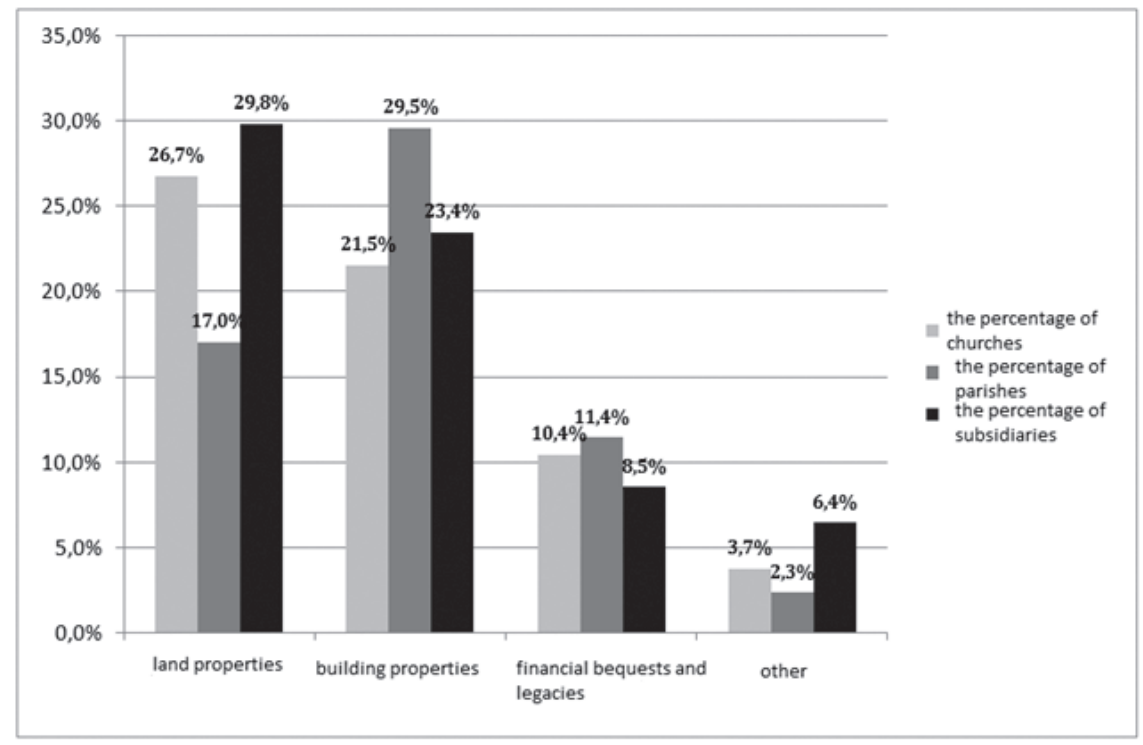

To sum up, when analyzing the visitation records of the years 1710-1712 from the angle of the church endowment, significant differences between the Archdeaconries of Pomorze and Kujawy are revealed. While in the case of the first one the visitor clearly distinguished dos ecclesiae from dos parochii, such formal differentiation was not recorded in the Archdeaconries of Włocławek and Kruszwica. There remains an open question about the regularity of such an approach. Were there such differences between the districts of the same diocese when we look from a broader chronological perspective -e.g. $16^{\text {th }}-18^{\text {th }}$ centuries? Another issue is a more detailed examination and comparison of the parish endowment, both for the priest and church. It should be noted, however, that studies on endowment require precise and very time-consuming research. The following article can only be a prelude to accurate and larger projects. Without doubt, the Diocese of Włocławek is a good research area, especially the exceptional and specific Archdeaconry of Pomorze, although the multiplicity and ambiguity of information about endowment, numerous and diverse sources of revenue, changeability of some components in time, exceptional detail of some source materials, or, in the case of others, the excessive vagueness, are not conducive to these types of topics.

Keywords: parish endowment, sextons, the Diocese of Włocławek, the Archdeaconry of Pomorze, canonical visitations 


\section{BIBLIOGRAFIA}

\section{Źródla rękopiśmienne}

Archiwum Archidiecezjalne w Gnieźnie

Visitatio archidaconatus Crusvicensis ex mandato (...) Constantini Szaniawski Dei et Apostolicae Sedis gratia episcopi Cuiaviensis et Pomeraniae per (...) Paulum Wolski, cancelarium Vladislaviensem archidiaconum Crusvicensem expedita Anno Dni 1712, sygn. E8.

Archiwum Diecezjalne w Pelplinie

Archidiaconatus Pomeraniae sub auspiciis (...) Constantini Feliciani de Szaniawy Szaniawski Episcopi Vladislaviensis et Pomeraniae per Joannem Casimirum Jugowski, Archidiaconum Pomeraniae visitatus A.D. 1710 et A.D. 1711, ADPel., sygn. G26.

Archiwum Diecezjalne we Włocławku

Visitatio ecclesiarum parochialium in archidaconatu Vladislaviensi, sub felici regimine (...) Constantini Feliciani Szaniawski, Dei et Apostolicae Sedis gratia episcopi Vladislaviens[si] et Pomeraniae, per (...) Joannem Stanislaum Borzysławski, archidaconum Vladislaviensem in anno Dni millesimo sepingentesimo undecimo expedita, sygn. W14(75).

\section{Źródla drukowane}

Statuta synodalia Dioecesis Wladislaviensis et Pomeraniae, collegit et edidit Zeno Chodyński, Varsaviae 1890.

\section{Opracowania}

Chodyński S., Biskupi sufragani włocławscy, Włocławek 1906.

Gręźlikowski J., Recepcja reformy trydenckiej w diecezji włocławskiej w świetle ustawodawstwa synodalnego, Włocławek 2000.

Karłowski K., Z dziejów zarządu majątku kościelnego, „Miesięcznik Kościelny. Organ Archidiecezji Gnieźnieńskiej i Poznańskiej”, 51(1936) s. 209-257.

Kumor B., Kościelne stowarzyszenia świeckich na ziemiach polskich w okresie przedrozbiorowym, „Prawo Kanoniczne”, 10 (1967) nr 1-2, s. 289-356.

Litak S., Atlas Kościoła łacińskiego w Rzeczypospolitej Obojga Narodów w XVIII w., Lublin 2006.

Litak S., Kościół łaciński w Rzeczypospolitej około 1772 r., Lublin 1996.

Nowicki T., Carbona ecclesiae - przyczynek do badań nad dochodowością kościołów parafialnych $\mathrm{w}$ archidiakonacie pomorskim na przykładzie wizytacji biskupa Rybińskiego z 1780-1781 roku, „Studia Pelplińskie”, 42 (2010), wyd. specjalne, s. 249259.

Nowicki T., Ministri ecclesiae. Służba kościelna i witrycy w diecezji włocławskiej w XVIII wieku, Lublin 2011.

Nowicki T., Przysięga witryków z początku XIX wieku - przyczynek do badań nad udziałem świeckich w zarządzie dobrami kościelnymi, w: Narrata de fontibus hausta. Studia nad problematyką kościelną, polityczną i archiwistyczną ofiarowane Janowi Skarbkowi w siedemdziesiątą rocznicę urodzin, red. A. Barańska, W. Matwiejczyk, Lublin 2010, s.231-238.

Nowicki T., Territoriale Herkunft der katholischen Geistlichkeit im Archidiakonat Pommerellen im 18. Jahrhundert, „Zeitschrift für Ostmitteleuropa-Forschung”, 49 (2000) Hf. 1, s. 19-37. 
Nowicki T., Uposażenie kleru parafialnego w archidiakonacie pomorskim w XVIII wieku, „Roczniki Humanistyczne”, 51 (2003) z. 2, s. 45-99.

Sołtyszewski S., Dochody kościelne pod zarządem witrykusów w polskim ustawodawstwie synodalnym, „Prawo Kanoniczne”, 3 (1960) nr 3-4, s. 311-333.

Sołtyszewski S., Geneza instytucji witrykusów w polskim ustawodawstwie synodalnym, „Prawo Kanoniczne”, 2 (1959) nr 1-2, s. 425-438.

Sołtyszewski S., Powoływanie witrykusów w polskim ustawodawstwie synodalnym, „Prawo Kanoniczne”, 2 (1959) nr 3-4, s. 341-357.

Sołtyszewski S., Prawa i obowiązki witrykusów w polskim ustawodawstwie synodalnym, „Prawo Kanoniczne”, 3 (1960), nr 1-2, s. 263-287.

Sołtyszewski S., Zarząd majątkiem kościelnym w kanonicznym ustawodawstwie powszechnym, "Prawo Kanoniczne" 3 (1960), nr 3-4, s. 335-346.

Wiśniewski J., Fabrica ecclesiae na terenie oficjalatu pomezańskiego w świetle wizytacji biskupich XVII-XVIII w., cz.1, „Archiwista Polski”, 12 (2007) nr 2, s. 47-56.

Wiśniewski J., Fabrica ecclesiae na terenie oficjalatu pomezańskiego w świetle wizytacji biskupich XVII-XVIII w., cz. 2, „Archiwista Polski”, 12 (2007) nr 4, s. 23-44.

Wiśniewski J., Fabrica ecclesiae na terenie oficjalatu pomezańskiego w świetle wizytacji biskupich XVII-XVIII w., cz. 3, „Archiwista Polski”, 13 (2008) nr 1, s. 69-76.

Wiśniowski E., Udział świeckich w zarządzie parafią w średniowiecznej Polsce, „Roczniki Humanistyczne", 18 (1970) s. 45-67.

Wójcik W., Instytucja witrykusów w świetle śląskich protokołów wizytacyjnych z XVII wieku, „Prawo Kanoniczne”, 6 (1963) nr 1-2, s. 49-74.

Wójcik W., „Prawa parafialne” według polskiego ustawodawstwa partykularnego do 1564 r., „Roczniki Teologiczno-Kanoniczne”, 3 (1957) z. 2, s. 153-226.

\section{DOS ECCLESIAE I DOS PAROCHII NA PRZYKLADZIE WIZYTACJI KANONICZNEJ PARAFII DIECEZJI WLOCŁAWSKIEJ Z LAT 1710-1711}

\section{Streszczenie}

W okresie staropolskim prawidłowe funkcjonowanie parafii było uzależnione od uposażenia jej w odpowiednie podstawy materialne. $Z$ jednej strony powinny one zabezpieczać byt rządcy kościoła, który za wykonywaną pracę duszpasterską otrzymywał zapłatę. Ta część dochodów nosiła w źródłach nazwy dos parochii, proventus parochi, bona beneficialia czy peculim clericale. Z drugiej strony w niektórych wizytacjach kanonicznych wymieniano i wyodrębniano, obok wspomnianego uposażenia plebańskiego, także inny rodzaj uposażenia zwany dos ecclesiae, proventus ecclesiae, reditus ecclesiae, bona fabricae czy też peculium ecclesiasticum. Pierwszym typem dochodów samodzielnie zarządzał pleban. Natomiast w przypadku drugiego w zarządzie pomagali mu świeccy wybrani spośród parafian, których zwano witrykami, witrykusami, prowizorami, czasem ekonomami, opiekunami, kustoszami czy szerokim kontekście ministrami kościoła. Omawiając zagadnienie uposażenia warto pamiętać o problemach związanych z wyodrębnieniem uposaże- 
nia plebańskiego i ściśle kościelnego. Nawet w dokładnych osiemnastowiecznych wizytacjach kościelnych nie zawsze wyodrębniano dos parochi i dos ecclesiae. Wprawdzie taki podział znało prawo kościelne już od średniowiecza, ale często w wizytacjach omawiano je łącznie w trakcie opisywania uposażenia parafii. Mogło być też tak, że nawet jeśli rozróżniano dos parochi od dos ecclesiae, to i tak dochodami na potrzeby fabryki kościoła gospodarował pleban, jako główny zarządca majątku kościelnego. Wówczas jednak to on musiał wyznaczyć niezbędne środki z całości dochodu uzyskiwanego z beneficjum - tak własnego plebańskiego, jak też tego przeznaczonego na kościół.

W przypadku przedrozbiorowej diecezji włocławskiej widać wyraźne kontrasty regionalne tak, jeśli chodzi o samą obecność witryków w parafiach, jak też o wyodrębnianie dochodów stricte kościelnych od plebańskich. Na początku XVIII wieku odsetek parafii ze prowizorami wynosił $\mathrm{w}$ archidiakonacie pomorskim niemal 56\%, z kolei we włocławskim nieco ponad 30\% i tylko w 2\% parafii w archidiakonacie kruszwickim. Pół wieku później dysproporcje były jeszcze bardziej wyraźne: witryków miało $76 \%$ parafii na Pomorzu, 27\% we Włocławskiem i jedynie 9\% w Kruszwickiem. Powyższe ustalenia potwierdza również analiza źródłowa zapisów dotyczących uposażenia beneficjalnego i kościelnego odnotowanych w omawianej wizytacji biskupa Szaniawskiego. Okazuje się, że w archidiakonacie pomorskim najczęściej, już na poziomie podtytułów wizytacyjnych, wyodrębniano dos ecclesiae i dos parochii. Próżno szukać takiego podziału w wizytacjach parafii kujawskich. Dokładniejsza analiza konkretnych zapisów źródłowych dotyczących świątyń archidiakonatu pomorskiego pokazuje, że na dochód stricte kościelny składały się nie tylko z zwykłe komponenty tego rodzaju uposażenia, jak np. składki zbierane w czasie nabożeństw czy należne kościołowi opłaty pogrzebowe. Uposażenie kościoła wyodrębniano od plebańskiego, gdy w grę wchodziły dodatkowe składniki, jak nieruchomości budowlane (domy, chaty czy mieszkania - niemal 27\% świątyń), nieruchomości gruntowe (pola, łąki, sady, ogrody, lasy czy wody $-21,5 \%$ ), zapisy pieniężne i legaty (ponad $10 \%$ ). Były też inne, lecz już mniej liczne składniki przynoszące dochód kościołom pomorskim, jak np. barcie pszczele czy legowane bydło. Wszystkie wpływy z tych źródeł trafiały do skarbony kościelnej, a o ich wydatkowaniu decydowali wspólnie pleban i witrycy.

Słowa kluczowe: uposażenie parafii, witrycy, diecezja włocławska, archidiakonat pomorski, wizytacje kanoniczne 